\title{
RUTGERS ACQUIRES THE NANDINO COLLECTION OF MODERN MEXICAN LITERATURE
}

\author{
BY FRANK N. DAUSTER \\ Professor of Romance Languages \\ College of Arts and Sciences, Rutgers University
}

7 HE University Library has recently acquired the personal library of the distinguished Mexican poet, Elías Nandino. Dr. Nandino, who has been closely associated with the major developments in Mexican poetry over a period of forty years, was recently honored by a public recital under the auspices of the National Institute of Fine Arts. In addition to his own poetry, he has been influential in publishing the work of many of his contemporaries; and the literary review Estaciones, which he founded and edited, was, from 1956 to 1960 , the most important outlet for young writers in Mexico. For the next four years, Dr. Nandino edited Cuadernos de Bellas Artes, the journal of the Institute of Fine Arts.

The Nandino collection includes some 700 volumes, and further strengthens the Library's extensive holdings in recent Mexican literature, placing it among the leaders in this field among American libraries. Although the collection includes a number of volumes of poetry and fiction, its major value to the University is the collection of literary periodicals beginning in I 928 . Included are journals such as Ulises and Contemporaneos, which were, from I 928 to I93 I, the organs of the "Generation of Contemporáneos," who were responsible for a major shift in Mexican esthetics in the direction of greater cosmopolitanism. Complete collections of these journals, along with the group's later publications, including Letras de Mexico, Romance, and others, are held by few libraries. The succeeding generation, led by Octavio Paz, is well represented by Taller and Taller Poético. These collections will provide greatly expanded research opportunities for both graduate students and faculty.

Although not, strictly speaking, a member of the "Generation of Contemporáneos," Dr. Nandino was a close personal friend of 
several of the most active members and worked closely with them in their efforts to revivify Mexican literature. Born in Cocula, Jalisco, he is a practicing surgeon, and has been Director of Treatment in a number of public and private hospitals; since I 950 he has maintained a private practice and directed his own clinic. His first book of poems, Canciones, appeared in I924, and he has continued to publish extensively since then. 